\title{
Simultaneous Determination of Catechins and Caffeine in Green Tea-Based Beverages and Foods for Specified Health Uses
}

\author{
Keiji Maruyama1 ${ }^{*}$, Fumiko Kihara-Negishi2, Naoki Ohkura ${ }^{3}$, Yasuhiro Nakamura1, \\ Miwako Nasui ${ }^{2}$, Moemi Saito ${ }^{1}$ \\ ${ }^{1}$ Research Center for Practical Training of Student Pharmacists, School of Pharma-Sciences, Teikyo University, Tokyo, Japan \\ ${ }^{2}$ Department of Life and Health Sciences, School of Pharma-Sciences, Teikyo University, Tokyo, Japan \\ ${ }^{3}$ Department of Medical and Pharmaceutical Sciences, School of Pharma-Sciences, Teikyo University, Tokyo, Japan \\ Email: ^kei-maru@pharm.teikyo-u.ac.jp, fumikokn@pharm.teikyo-u.ac.jp
}

How to cite this paper: Maruyama, K., Kihara-Negishi, F., Ohkura, N., Nakamura, Y., Nasui, M. and Saito, M. (2017) Simultaneous Determination of Catechins and Caffeine in Green Tea-Based Beverages and Foods for Specified Health Uses. Food and Nutrition Sciences, 8, 316-325.

https://doi.org/10.4236/fns.2017.83021

Received: January 25, 2017

Accepted: March 10, 2017

Published: March 13, 2017

Copyright () 2017 by authors and Scientific Research Publishing Inc. This work is licensed under the Creative Commons Attribution International License (CC BY 4.0).

http://creativecommons.org/licenses/by/4.0/

\begin{abstract}
Catechins in green tea have various useful features including antioxidant activity and preventive effects on metabolic syndrome. Various beverages that are enriched with tea catechins are marketed as Foods for Specified Health Uses (FOSHU) in Japan. However, recent reports have indicated that excessive consumption of green tea extracts as a dietary supplement are associated with adverse health effects such as liver disorders. Various catechins and caffeine are constituents of FOSHU tea-based beverages. The amount of catechins in FOSHU products is displayed on labels as total catechin content, but the content of individual catechins are not provided. Although health hazards of FOSHU products have rarely been reported, precise information about the content and types of catechins in FOSHU products is needed to ensure safety. We used high-performance liquid chromatography with a photodiode array (HPLC/PDA) to simultaneously identify and quantify catechins and caffeine in green tea-based popular beverages and FOSHU beverages. This technique allowed simultaneous quantitation of five types of catechins and caffeine in green tea without complicated sample preparation. Epigallocatechin gallate (EGCG) and epigallocatechin EGC were the main catechins in various FOSHU beverages and the concentrations of almost all catechins were higher in FOSHU, than in popular green tea-based beverages. The concentrations of EGCG in green tea-based popular beverages and in FOSHU beverages were $5.4-7.3$ and $10.2-41.9 \mathrm{mg} / 100 \mathrm{~mL}$, respectively, with the highest concentration being in a product named Healthya (approximately $147 \mathrm{mg} /$ bottle). The simultaneous determination of compounds such as catechins and caffeine in FOSHU beverages can help to estimate beneficial and adverse effects to pre-
\end{abstract}


vent deleterious effects on health and the excessive consumption of FOSHU beverages containing high concentrations of tea catechins should be avoided.

\section{Keywords}

Simultaneous Quantitation, High-Performance Liquid

Chromatography-Photodiode, Catechin, Caffeine, Health Food,

Dietary Supplement

\section{Introduction}

Tea produced from the leaves of Camellia sinensis is the most common beverage consumed worldwide. It is categorized as green, oolong, or black, depending on whether the tea leaves are nonfermented, partially fermented, or completely fermented/oxidized, respectively.

Green tea prepared from processed leaves of Camellia sinensis, contains large amounts of polyphenols, most of which are catechins. Catechins account for $10 \%-20 \%$ of dry green tea leaves and those are described as being responsible for the bitter components of green tea. The major types of catechins in green tea are epigallocatechin gallate (EGCG), epigallocatechin (EGC), epicatechin (EC) and epicatechingallate (ECG), along with their heat-induced isomers that include catechin $(+C)$, gallocatechin (GC), catechingallate (CG), and gallocatechingallate (GCG). Among these, EGCG has been extensively investigated since it is the dominant catechin in green tea.

Green tea is widely recognized as a health beverage worldwide, because catechins possess antioxidant, anticarcinogenic [1] [2], fat-burning [3] and anti-obesity [4] effects, as well as properties that can help to cure metabolic syndrome [5]. The Consumer Affairs Agency of Japan has approved the marketing of catechin-rich tea beverages as FOSHU products due to the various health-promoting functions of catechins. Because adverse health effects of consuming green tea or catechin-rich tea beverages have not been reported, catechins are considered safe. However, recent reports indicate that the over-consumption of dietary supplements containing high doses of tea catechins can cause liver disorders associated with catechin-induced hepatotoxicity [6]. It is also reported that higher oral doses of EGCG are hepatotoxic to mice [7]. The amounts of catechins in bottled FOSHU products are displayed on labels as total catechin content, but the contents of individual catechins are not. Therefore, concentrations of individual catechins in catechin-rich tea beverages should be determined and displayed to ensure the safe and appropriate consumption of catechins. Furthermore, excessive consumption of caffeine can cause sleep disturbances, gastrointestinal disorders, arrhythmia and acute seizures. Here, we used a photodiode array (PDA) with HPLC detection to compare the concentrations of individual catechins and caffeine in FOSHU beverages with those in popular green tea-based Japanese beverages. 


\section{Materials and Methods}

\subsection{Materials}

Authentic standards of EGCG, EGC, EC, ECG and +C (Green Tea Catechin Standards Kit) catechins and caffeine (JIS Special Grade) were obtained from Chroma Dex and Wako Pure Chemical Industries Ltd., respectively. Other reagents were of JIS Special or HPLC grade.

\subsection{Preparation of Standard and Tea Beverage Samples}

A mixture of authentic catechins and caffeine was dissolved in Milli-Q water supplemented with equimolar or higher concentrations of ascorbic acid antioxidant as standard stock solutions and stored at $-30^{\circ} \mathrm{C}$. The composition in standard solution was EGCG $(200 \mu \mathrm{g} / \mathrm{mL})$, EGC $(200 \mu \mathrm{g} / \mathrm{mL})$, EC $(200 \mu \mathrm{g} / \mathrm{mL})$, ECG $(100 \mu \mathrm{g} / \mathrm{mL}),+\mathrm{C}(100 \mu \mathrm{g} / \mathrm{mL})$ and caffeine $(400 \mu \mathrm{g} / \mathrm{mL})$. Standard stock solutions were immediately diluted with Milli- $\mathrm{Q}$ water before use as working solutions to prepare calibration curves. Stock solutions of catechins and caffeine remained stable when frozen for at least two months. Four branded FOSHU beverages marketed in bottled, ready-to-drink form were purchased as follows: Healthya (Kao Corporation Tokyo Japan; lot, 2014.10.29/H), Iyemon Tokucha (Suntory Beverage \& Food Ltd., Tokyo Japan; lot, 2014.12.19/T), Catechin Ryokucha (Itoen Ltd., Tokyo Japan; lot, A13' 14:52) and Juroku-cha W (Asahi Soft Drinks Co. Ltd. Tokyo Japan; lot, 14.11.27/F). Five bottled, ready-to-drink, green teabased beverages were also purchased as follows: Nama-cha (Kirin Beverage Corporation; lot 150212/T), Iyemon (Suntory; lot 2014.12.21/T), Ayataka (The Coca-Cola company; lot 141216-ESA c19520231876882), OiOcha (Itoen; lot 2015.2.8 K50) and Oi Ocha Dark (Itoen; lot 2015.2.4 K50). Frozen standard solutions and beverage samples were diluted 10 -fold with Milli-Q water and filtered through a $0.45-\mu \mathrm{m}$ membrane immediately before HPLC analysis.

\subsection{HPLC Conditions}

Samples were analyzed using a Shimadzu Prominence system equipped with an LC-20AB pump, DGU-20A3R degasser, SIL-20ACHT autosampler, CTO-10AS vp column oven, SPD-20A UV-VIS detector, SPD-M20A PDA detector and a LabSolutions data processor. The HPLC conditions were as follows: column, Shiseido CAPCELL PAK C18 MG (5 m, 4.6 mm I.D. × $150 \mathrm{~mm}$ ); mobile phase, $0.5 \%$ aqueous phosphoric acid (A) and methanol/acetonitrile (9:1) (B); solvent gradient (A:B), 80:20 over 0 - $10 \mathrm{~min}$, followed by a linear gradient to 60:40 over $30 \mathrm{~min}$; flow rate, $1 \mathrm{~mL} / \mathrm{min}$; column temperature, $40^{\circ} \mathrm{C}$; and detection wavelength, 242 and $272 \mathrm{~nm}$. The injected volume was $10 \mu \mathrm{L}$. The wavelength range for absorption spectrum analysis by PDA was set at $190-400 \mathrm{~nm}$.

\subsection{Precision and Accuracy}

The precision and accuracy of the HPLC method were evaluated by analyzing three concentrations of catechin working standard solutions prepared by adding 
various concentrations of stock solution to green tea. Assay precision determined as intra-day ( $\mathrm{n}=5$ samples) and inter-day ( $\mathrm{n}=5$ days) variability is expressed as percent relative standard deviation (\%RSD). \%RSD was calculated using the percentage ratio of standard deviation to the means of five replicate determinations. $\%$ RSD $=$ standard deviation/mean $\times 100$. Accuracy was assessed as \% recovery.

\section{Results and Discussion}

\subsection{Peak Spectral Similarity}

We simultaneously measured the concentrations of the major catechins EGCG, EGC, EC, ECG, and + C, and caffeine (Figure 1) using a gradient method. Figure 2 shows chromatograms and contour maps of catechins and caffeine. Peaks were identified based on computed similarity indices $>0.9$ for the absorption spectra of peaks with the same retention times in chromatograms of standard solutions containing authentic compounds (Figure 2(a)) and green tea-based beverages (Figure 2(b)). This method allowed the separation of EGCG, EGC, $\mathrm{EC}, \mathrm{ECG}+\mathrm{C}$ and caffeine into six discrete peaks without complicated sample preparation or interference from other components of the samples.

\subsection{Quantitative Analysis of Catechins and Caffeine}

Catechins and caffeine were quantified using an absolute calibration curve. The<smiles>O=C(O[C@H]1CC2C(O)=CC(O)=CC2OC1c1cc(O)c(O)c(O)c1)c1cc(O)c(O)c(O)c1</smiles>

1. Epigallocatechin gallate (EGCG)<smiles>O=C(O[C@H]1CC2C(O)=CC(O)=CC2OC1c1ccc(O)c(O)c1)c1cc(O)c(O)c(O)c1</smiles>

4. Epicatechin gallate (ECG)<smiles>C[C@]1(O)CC2C(O)=CC(O)=CC2OC1c1cc(O)c(O)c(O)c1</smiles>

2. Epigallocatechin (EGC)<smiles>OC1=CC2OC(c3ccc(O)c(O)c3)[C@H](O)CC2C(O)=C1</smiles>

5. Catechin $(+C)$<smiles>OC1=CC2OC(c3ccc(O)c(O)c3)[C@H](O)CC2C(O)=C1</smiles>

3. Epicatechin (EC)<smiles>Cn1c(=O)c2c(ncn2C)n(C)c1=O</smiles>

6. Caffeine

Figure 1. Structure of catechins and caffeine. 


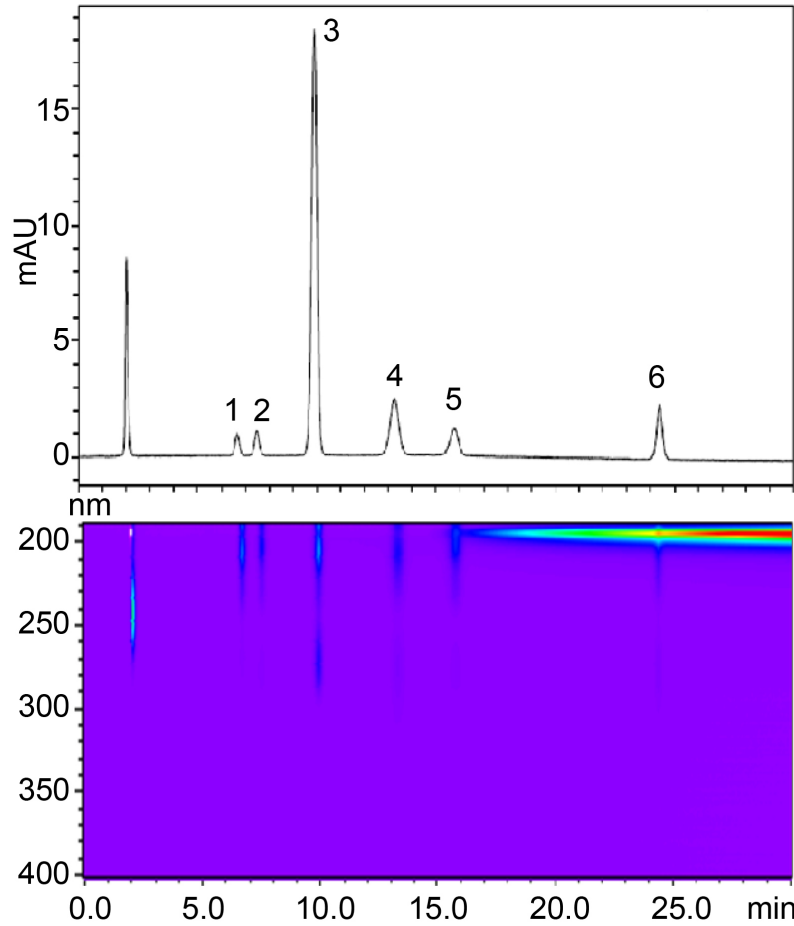

(a)

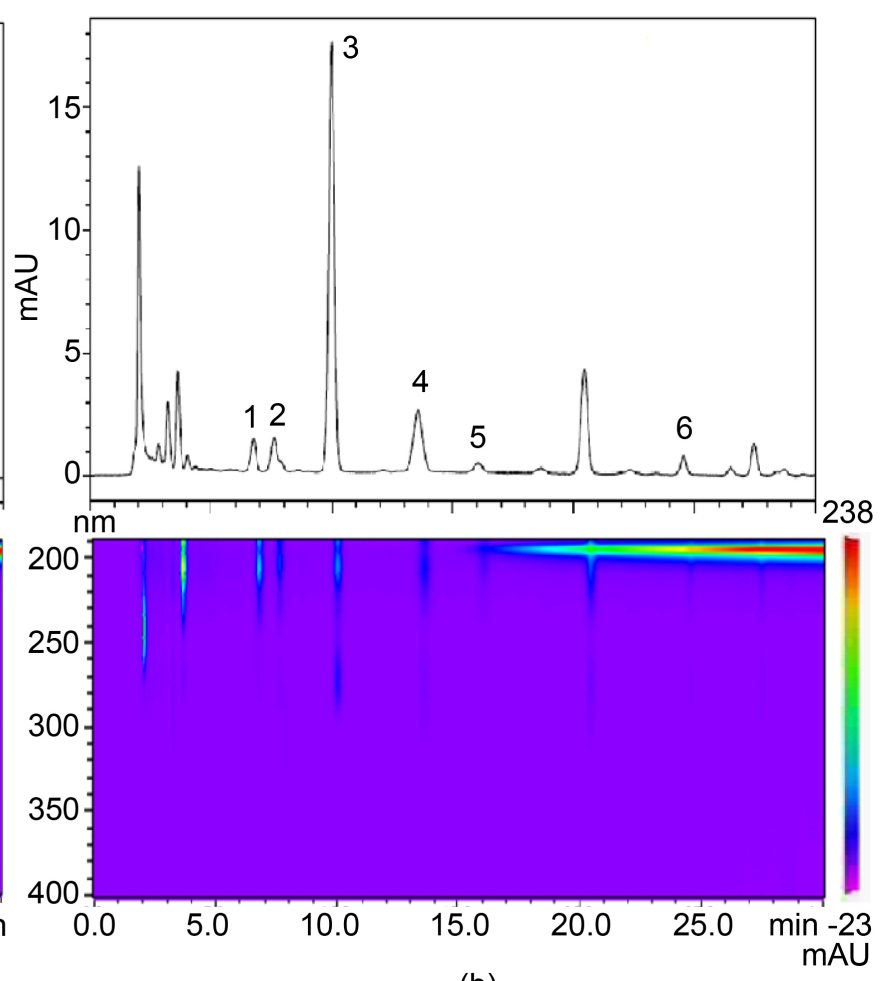

(b)

Figure 2. Chromatograms and contour maps of caffeine and catechins in standard solution (a) and green tea (b). 1, EGC; 2, +C; 3, Caffeine; 4, EGCG; 5, EC; 6, ECG.

detection wavelength was set at $242 \mathrm{~nm}$ for EGC and +C, and $272 \mathrm{~nm}$ for EGCG, EC, ECG and caffeine. Table 1 shows the range of calibration curves and parameters of the limits of detection and quantitation for each component. The detection and quantitation limits calculated from the residual standard deviation of the regression line of the calibration curve were 3.3- and 10-fold, respectively. The quantitation limits for EGCG, EGC, EC, ECG, + C and caffeine were 0.27, $0.14,0.62,0.29,0.03$, and $0.34 \mu \mathrm{g} / \mathrm{mL}$, respectively, indicating that this assay is sensitive enough to measure catechins in green tea beverages. The calibration curve was quite linear $(r=1.000$, data not shown) and within the concentration range listed in Table 1 for each component.

\subsection{Assay Precision and Accuracy}

Table 2 and Table 3 respectively show the precision and accuracy of catechin and caffeine measurements. The \%RSD for catechins and caffeine were both < $3 \%$ for intra- and inter-day variations, indicating good assay repeatability. Recovery ranged from $92 \%$ to $108 \%$ for catechins and caffeine, respectively, in this assay. Catechins and caffeine and remained stable for at least 16 hours in the in the HPLC autosampler at $4^{\circ} \mathrm{C}$ (data not shown).

\subsection{Catechin and Caffeine Concentrations in Green Tea-Based Popular and FOSHU Beverages}

The major types of catechins, a group of polyphenols found abundantly in green 
Table 1. Analytical parameters for determination of catechins and caffeine.

\begin{tabular}{ccccccc}
\hline & EGCG & EGC & EC & ECG & + C & Caffeine \\
\hline $\begin{array}{c}\text { Linear range } \\
(\mu \mathrm{g} / \mathrm{mL})\end{array}$ & $1.25-20$ & $1.25-20$ & $1.25-20$ & $0.625-10$ & $0.625-10$ & $2.5-40$ \\
$\begin{array}{c}\text { Detection limit } \\
(\mu \mathrm{g} / \mathrm{mL})\end{array}$ & 0.09 & 0.05 & 0.20 & 0.09 & 0.01 & 0.11 \\
$\begin{array}{c}\text { Quantification } \\
\text { limit }(\mu \mathrm{g} / \mathrm{mL})\end{array}$ & 0.27 & 0.14 & 0.62 & 0.29 & 0.03 & 0.34 \\
\hline
\end{tabular}

Table 2. Precision and accuracy of catechins in green tea spiked with catechins.

\begin{tabular}{|c|c|c|c|c|c|c|c|}
\hline \multirow{3}{*}{ Catechins } & \multicolumn{3}{|c|}{ Theoretical Concentration } & \multirow{3}{*}{$\begin{array}{l}\text { Determined }^{*} \\
\qquad(\mu \mathrm{g} / \mathrm{mL})\end{array}$} & \multirow{2}{*}{\multicolumn{2}{|c|}{ Precision (\%RSD) }} & \multirow{3}{*}{$\begin{array}{c}\text { Accuracy (\% } \\
\text { Intra-day }\end{array}$} \\
\hline & \multicolumn{3}{|c|}{$(\mu \mathrm{g} / \mathrm{mL})$} & & & & \\
\hline & Original $^{*}$ & Added & Total $^{*}$ & & Intra-day & Inter-day & \\
\hline \multirow{3}{*}{ EGCG } & 6.67 & 2.5 & 9.17 & 9.05 & 0.77 & 0.83 & 95.3 \\
\hline & 6.67 & 5.0 & 11.67 & 11.47 & 0.98 & 1.43 & 96.1 \\
\hline & 6.67 & 10.0 & 16.67 & 16.12 & 0.98 & 1.97 & 94.6 \\
\hline \multirow{3}{*}{ EGC } & 7.13 & 2.5 & 9.63 & 9.56 & 0.43 & 1.48 & 97.3 \\
\hline & 7.13 & 5.0 & 12.13 & 12.05 & 1.01 & 1.56 & 98.5 \\
\hline & 7.13 & 10.0 & 17.13 & 16.99 & 0.47 & 1.68 & 98.6 \\
\hline \multirow{3}{*}{$\mathrm{EC}$} & 1.74 & 2.5 & 4.24 & 4.29 & 0.68 & 1.96 & 101.7 \\
\hline & 1.74 & 5.0 & 6.74 & 6.67 & 0.67 & 1.62 & 98.6 \\
\hline & 1.74 & 10.0 & 11.74 & 11.65 & 0.57 & 1.52 & 99.1 \\
\hline \multirow{3}{*}{ ECG } & 1.19 & 1.25 & 2.44 & 2.35 & 0.91 & 0.63 & 92.9 \\
\hline & 1.19 & 2.50 & 3.69 & 3.49 & 0.77 & 1.69 & 92.0 \\
\hline & 1.19 & 5.00 & 6.19 & 5.79 & 1.19 & 2.51 & 92.1 \\
\hline \multirow{3}{*}{$+\mathrm{C}$} & 2.50 & 1.25 & 3.75 & 3.75 & 0.81 & 1.78 & 100.2 \\
\hline & 2.50 & 2.50 & 5.00 & 4.98 & 0.77 & 2.53 & 99.4 \\
\hline & 2.50 & 5.00 & 7.50 & 7.87 & 1.03 & 2.01 & 107.5 \\
\hline
\end{tabular}

*: Mean of five replicate determinations.

Table 3. Precision and accuracy of caffeine in green tea spiked with caffeine.

\begin{tabular}{|c|c|c|c|c|c|c|}
\hline \multicolumn{3}{|c|}{ Theoretical Concentration $(\mu \mathrm{g} / \mathrm{mL})$} & \multirow{2}{*}{$\begin{array}{l}\text { Determined } \\
\quad(\mu \mathrm{g} / \mathrm{mL})\end{array}$} & \multicolumn{2}{|c|}{ Precision (\%RSD) } & \multirow{2}{*}{$\begin{array}{c}\text { Accuracy } \\
(\%)\end{array}$} \\
\hline Original $^{\star}$ & Added & Total $^{\star}$ & & Intra-day & Inter-day & \\
\hline 11.1 & 5.0 & 16.1 & 16.1 & 0.42 & 0.90 & 99.7 \\
\hline 11.1 & 10.0 & 21.1 & 21.4 & 0.85 & 1.44 & 100.8 \\
\hline 11.1 & 20.0 & 31.1 & 31.1 & 0.51 & 1.67 & 98.9 \\
\hline
\end{tabular}

*: Mean of five replicate determinations.

tea, comprise EGCG, EGC, ECG and EC and EGCG, with EGC being predominant. We simultaneously determined and compared the concentrations of five catechins and caffeine in green tea-based popular beverages and FOSHU beverages using HPLC/PDA. Table 4 shows the catechin concentrations in the pop- 
ular beverages. The EGCG concentration was highest in Oi Ocha Dark followed by Ayataka and Iyemon $(15.8,7.33$ and $7.17 \mathrm{mg} / 100 \mathrm{~mL}$, respectively). The EGC concentration also followed the same order $(11.9,9.46$ and $7.91 \mathrm{mg} / 100 \mathrm{~mL}$, respectively). Oi Ocha Dark contained about double the EGCG and EGC concentrations compared with Oi Ocha, another product of the same company, and the concentrations of other catechins for Oi Ocha dark were highest among the popular green tea beverages. Table 5 shows the catechin concentrations in the FOSHU beverages. The main catechins were EGCG and EGC and the concentrations of almost all catechins in FOSHU except EC in Catechin Ryokucha were higher than those of green tea-based popular beverages. Healthya contained the most EGCG among all tested FOSHU beverages. The caffeine concentration was also higher in FOSHU, than popular beverages and it was highest in Healthya $(23.9 \mathrm{mg} / 100 \mathrm{~mL})$ among the FOSHU beverages. These results showed that catechin contents differ between green tea-based popular beverages and FOSHU beverages, and that the contents of the main catechins EGCG and EGC as well as caffeine were the highest in Healthya. Differences in spices, leaves and/or processes used to produce these beverages might be responsible for these differences.

Popular green tea-based and FOSHU beverages are marketed in 500 - 555and $350-600-\mathrm{mL}$ bottles, respectively. Thus, the estimated EGCG contents per bottle of popular and FOSHU beverages are $30-80$ and $50-145 \mathrm{mg}$, respectively, for the FOSHU beverages except Juroku-cha W. Notably, the estimated amount of EGCG in one bottle of Healthya was equivalent to that in $3-4$ bottles

Table 4. Catechin and caffeine concentrations in popular green tea beverages.

\begin{tabular}{cccccccc}
\hline \multirow{2}{*}{ brand } & $\begin{array}{c}\text { serving size } \\
(\mathrm{mL})\end{array}$ & EGCG & EGC & EC & ECG & + + & Caffeine \\
\cline { 3 - 7 } & 555 & 5.40 & 7.32 & 1.48 & 0.88 & 3.45 & 9.16 \\
\hline $\begin{array}{c}\text { Nama-cha } \\
\text { Iyemon }\end{array}$ & 500 & 7.17 & 7.91 & 2.04 & 1.28 & 2.88 & 13.2 \\
Ayataka & 525 & 7.33 & 9.46 & 2.30 & 1.30 & 3.51 & 12.3 \\
Oi ocha & 525 & 5.78 & 5.80 & 1.28 & 0.97 & 2.83 & 11.0 \\
Oi ocha & & & & & & & 1.0 \\
dark & 525 & 15.8 & 11.9 & 3.05 & 2.80 & 5.18 & 17.7 \\
\hline
\end{tabular}

*: Mean of five replicate determinations.

Table 5. Catechin and caffeine concentrations in Food for Specified Health Uses (FOSHU).

\begin{tabular}{cccccccc}
\hline \multirow{2}{*}{ brand } & $\begin{array}{c}\text { serving size } \\
(\mathrm{mL})\end{array}$ & \multicolumn{5}{c}{${\text { concentration }(\mathrm{mg} / 100 \mathrm{~mL})^{*}}^{*}$} \\
\cline { 3 - 7 } & 350 & 41.9 & 34.3 & 9.20 & 10.6 & 8.91 & 23.9 \\
Healthya & 500 & 10.2 & 9.02 & 2.37 & 2.09 & 2.30 & 17.5 \\
Iyemon Tokucha & 350 & 19.7 & 3.41 & 0.78 & 5.20 & 1.78 & 7.51 \\
Catechin Ryokucha & 600 & 0.30 & ND & ND & ND & ND & 3.20 \\
Juroku-cha W & 600 & & & & & & EC \\
\hline
\end{tabular}

*: Mean of five replicate determinations. 
of popular tea-based beverages. Both EGCG and EGC are thought to have various physiological functions. For example, tea catechins decrease cholesterol and triglyceride levels. Among tea catechins, EGCG reduces intestinal cholesterol absorption, increases LDL receptor gene expression and inhibits LDL oxidation [8] [9]. Studies have shown that EGCG can inhibit LDL oxidation and green tea consumption of $700-800 \mathrm{~mL} /$ day can reduce cardiovascular risk [10]. Furthermore, tea catechins combined with caffeine decrease lipogenesis and increase lipolysis [11] [12]. Therefore, one bottle per day of Healthya, which contains the most caffeine and tea catechins, including amounts of EGCG equivalent to those in $>1000 \mathrm{~mL}$ of popular beverages, is sufficient to benefit from its health-promoting effects.

The consumption of these FOSHU beverages should be limited to about one bottle per day from the viewpoint of safety because recent reports suggest that excessive consumption of green tea extract can impair liver function. Survey data collected between 1999 and 2008 identified 34 patients ( 6 men and 28 women) with liver disorders associated with green tea consumption, and 15 of them also consumed a dietary supplement containing exclusively green tea extract [13]. Hepatic inflammation accompanied by increased blood levels of hepatic enzymes (ALT, ALP and total bilirubin) and biopsy-proven necrosis has occurred in a 24-year-old Caucasian woman with the $\alpha$ - 1 antitrypsin MZ phenotype who swallowed two caplets of a dietary supplement containing $135 \mathrm{mg}$ of EGCG twice daily (EGCG $540 \mathrm{mg} /$ day) for three months [14]. Acute liver failure has occurred in a 16-year-old Hispanic boy who consumed two tablets of a dietary supplement containing $400 \mathrm{mg}$ of EGCG daily for 60 days [15]. Therefore, excessive consumption of Healthya containing a high concentration of EGCG might deleteriously affect liver function, whereas consuming one bottle a day of Healthya can positively benefit beneficial health. Furthermore, excessive consumption of caffeine can cause sleep disturbances, gastrointestinal disorders, arrhythmia and acute seizures. Taken together, the excessive consumption of dietary supplements, health foods and FOSHU products containing extracted and/or concentrated catechins and caffeine should be avoided, although ingesting catechins and caffeine in popular green tea beverages is harmless, and probably beneficial.

\section{Conclusion}

The simultaneous determination of catechins and caffeine levels in individual green tea-based, popular and FOSHU beverages using HPLC with a PDA detector was selective. Our original methods indicated in this paper are simple and useful. It has the small application scale and a high sensitivity. Then, it is applicable in the simultaneous determination of catechins and caffeine levels in other tea-based FOSHU beverages such as oolong or black tea. We found that the FOSHU beverages contained equivalent amounts of EGCG and caffeine to those in 3 - 4 bottles of popular green tea-based beverages. Therefore, the consumption of green tea-based FOSHU beverages to promote health should be limited 
to one bottle per day. Simultaneous determination of EGCG and caffeine in FOSHU beverages is useful for correctly identifying their positive and negative effects and the consumption of these beverages must be appropriate to realize their health-promoting benefits.

\section{References}

[1] Lambert, J.D. and Elias, R.J. (2010) The Antioxidant and Pro-Oxidant Activities of Green Tea Polyphenols: A Role in Cancer Prevention. Archives of Biochemistry and Biophysics, 501, 65-72. https://doi.org/10.1016/j.abb.2010.06.013

[2] Yang, C.S., Lambert, J.D. and Sang, S. (2009) Antioxidative and Anti-Carcinogenic Activities of Tea Polyphenols. Archives of Toxicology, 83, 11-21. https://doi.org/10.1007/s00204-008-0372-0

[3] Ota, N., Soga, S., Shimotoyodome, A., Haramizu, S., Inaba, M., Murase, T. and Tokimitsu, I. (2005) Effects of Combination of Rgulation Exercise and Tea Catechins Intake on Energy Expenditure in Humans. Journal of Health Science, 51, 233-236. https://doi.org/10.1248/jhs.51.233

[4] Kao, Y.H., Chang, H.H., Lee, M.J. and Chen, C.L. Mol. (2006) Tea, Obesity, and Diabetes. Molecular Nutrition \& Food Research, 50, 188-210. https://doi.org/10.1002/mnfr.200500109

[5] Basu, A., Sanchez, K., Leyva, M.J., Wu, M., Betts, N.M., Aston, C.E. and Lyons, T.J. (2010) Green Tea Supplementation Affects Body Weight, Lipids, and Lipid Peroxidation in Obese Subjects with Metabolic Syndrome. Journal of the American College of Nutrition, 29, 31-40. https://doi.org/10.1080/07315724.2010.10719814

[6] Molinari, M., Watt, K.D., Kruszyna, T., Nelson, R., Walsh, M., Huang, W.Y., Nashan, B. and Peltekian, K. (2006) Acute Liver Failure Induced by Green Tea Extracts: Case Report and Review of the Litreature. Liver Transplantaion, 12, 18921895. https://doi.org/10.1002/lt.21021

[7] Lambert, J.D., Kennett, M.J., Sang, S., Reuhl, K.R., Ju, J. and Yang, C.S. (2010) Hepatotoxicity of High Oral Dose (-)-Epigallocatechin-3-Gallate in Mice. Food and Chemical Toxicology, 48, 409-416. https://doi.org/10.1016/j.fct.2009.10.030

[8] Kobayashi, M., Nishizawa, M., Inoue, N., Hosoya, T., Yoshida, M., Ukawa, Y., Sagesaka, Y.M., Doi, T., Nakayama, T., Kumazawa, S. and Ikeda, I. (2014) Epigallocatechin Gallate Decreases the Micellar Solubility of Cholesterol via Specific Interaction with Phosphatidylcholine. Journal of Agricultral and Food Chemistry, 62, 28812890. https://doi.org/10.1021/jf405591g

[9] Goto, T., Saito, Y., Morikawa, K., Kanamaru, Y. and Nagaoka, S. (2012) Epigallocatechin Gallate Changes mRNA Expression Level of Genes Involved in Cholesterol Metabolism in Hepatocytes. British Journal of Nutrition, 107, 769-773. https://doi.org/10.1017/S0007114511003758

[10] Miura, Y., Chiba, T., Miura, S., Tomita, I., Umegaki, K., Ikeda, M. and Tomita, T. (2000) Green Tea Polyphenols (Flavan 3-Ols) Prevent Oxidative Modification of Low Density Lipoproteins: An ex Vivo Study in Humans. Journal of Nutrition and Biochemistry, 11, 216-222. https://doi.org/10.1016/S0955-2863(00)00068-1

[11] Sayama, K., Lin, S., Zheng, G. and Oguni, I. (2000) Effects of Green Tea on Growth, Food Utilization and Lipid Metabolism in Mice. In Vivo, 14, 481-484.

[12] Sugiura, C., Nishimatsu, S., Moriyama, T., Ozasa, S., Kawada, T. and Sayama, K. (2012) Catechins and Caffeine Inhibit Fat Accumulation in Mice through the Improvement of Hepatic Lipid Metabolism. Journal of Obesity, 2012, Article ID: 520510. https://doi.org/10.1155/2012/520510 
[13] Mazzanti, G., Menniti-Ippolito, F., Moro, P.A., Cassetti, F., Raschetti, R. and Santuccio, C. and Mastrangelo, S. (2009) Hepatotoxicity from Green Tea: A Review of the Literature and Two Unpublished Cases. European Journal of Clinical Pharmacology, 65, 331-341. https://doi.org/10.1007/s00228-008-0610-7

[14] Weinstein, D.H., Twaddell, W.S., Raufman, J.P., Philosophe, B. and Mindikoglu, A.L. (2012) SlimQuick ${ }^{\mathrm{Tm}}$-Associated Hepatotoxicity in a Woman with Alpha-1 Antitrypsin Heterozygosity. World Journal of Hepatology, 4, 154-157. https://doi.org/10.4254/wjh.v4.i4.154

[15] Patel, S.S., Beer, S., Kearney, D.L., Phillips, G. and Carter, B.A. (2013) Green Tea Extract: A Potential Cause of Acute Liver Failure. World Journal of Gastroenterology, 19, 5174-5177. https://doi.org/10.3748/wjg.v19.i31.5174

Submit or recommend next manuscript to SCIRP and we will provide best service for you:

Accepting pre-submission inquiries through Email, Facebook, LinkedIn, Twitter, etc. A wide selection of journals (inclusive of 9 subjects, more than 200 journals)

Providing 24-hour high-quality service

User-friendly online submission system

Fair and swift peer-review system

Efficient typesetting and proofreading procedure

Display of the result of downloads and visits, as well as the number of cited articles Maximum dissemination of your research work

Submit your manuscript at: http://papersubmission.scirp.org/

Or contact fns@scirp.org 